\title{
Sociology in Germany After 1990
}

After Hungary had opened its borders to Austria in May 1989, numerous citizens of the GDR were able to travel to the FRG via Austria. This increased the pressure on the GDR leadership. They could not expect any help from Mikhail Gorbachev. Rather, Gorbachev's reform politics of "glasnost" and "perestroika" encouraged the opposition groups. Many of these groups had supported the peace movement in the GDR in the 1980s and had already formed networks. However, it had become clear that the protesters did not aim for the end of the GDR, but for "a different GDR" (Conze 2009, pp. 689, 694). ${ }^{1}$ In September 1989, the Neue Forum (New Forum) had been founded, as well as the group Demokratie Jetzt (Democracy Now); this was followed by the foundation of the Sozialdemokratische Partei in der DDR (Social Democratic Party in the GDR). It was not only the emigrants who advanced the transformation process of the GDR; the SED regime (Sozialistischen Einbeitspartei Deutschlands) was, to a large extent, brought down by the aforementioned political groups, that is, by people who were still remaining in the GDR. The growing commitment of the people eventually became evident in the ever-growing "Monday demonstrations" in Leipzig.

The images of the demonstrations in Leipzig, especially the "Monday demonstration" of October 9, 1989, which was attended by 70,000

\footnotetext{
${ }^{1}$ In the following brief summary of the historical developments, I refer mainly to Conze (2009) and Görtemaker $(2004,2009)$.
}

(C) The Author(s) 2021

S. Moebius, Sociology in Germany, Sociology Transformed, https://doi.org/10.1007/978-3-030-71866-4_6 
people, suggested that profound social and political changes were taking place within the society of the GDR. The GDR was in a deep crisis; by that time even the GDR leadership realized this. It was losing more and more control. In October, finally, the General Secretary Erich Honecker had to resign. The power of the state party, the SED, decayed ever more.

A central date was November 9, 1989. As already mentioned in Chap. 5, at a press conference the secretary of the Central Committee Günter Schabowski presented new travel regulations and declared the possibilities for traveling abroad to be "effective immediately". As a result, thousands headed for the border crossings and finally to West Berlin. The Wall fell.

In the beginning, confederative relations between the GDR and the FRG were still being considered (and many of the civil rights activists had been hoping for these relations); however, the situation changed due to economic and political developments. While in 1989 the GDR's productivity lagged $45 \%$ behind that of West Germany (Heske 2005, p. 76), the GDR was now increasingly in danger of an economic collapse. Former trading partners of the "Eastern Bloc" were themselves in crisis and GDR products were increasingly in competition with West German consumer goods. Numerous citizens left the GDR and sought their fortune in the West. Politically, the GDR government lacked popular support. This dynamic led to the reunification of Germany becoming more realistic than a two-state solution or confederation.

Expectations were high. With the fall of the Berlin Wall, the social problems of the Federal Republic, which became increasingly apparent in the 1980s, faded into the background for a short time. For a few months there was a mood of "collective effervescence" (Durkheim). This situation of transformation in part corresponded to a "liminal phase" (van Gennep), which, according to Victor Turner (1969), is characterized by a great sense of community ("communitas"). Everything seemed possible, although it was not yet certain that the protests of autumn 1989 would result in German reunification-it was a highly contingent situation.

After a few weeks, however, the initial enthusiasm gave way to disillusionment, not because of the collapse of the GDR, but because of the ways and effects of the process of transformation. At first, the protest groups that had contributed a great deal to the fall of the Berlin Wall were disappointed. In the process of transformation, they lost their leading political role. Moreover, they had not hoped for a takeover of the GDR by the FRG, but for a transformation of the GDR. However, the political weight of the FRG and of Chancellor Helmut Kohl was too great. Kohl 
pushed for a quick reunification. In March 1990, elections were held in the GDR. The winning parties were not only those that wanted to join the FRG quickly, but also those that had the decisive support of the established West German parties. On August 23, 1990, the new government of the GDR decided on the GDR's accession to the FRG as of October 3, 1990. On this date, Germany was officially reunified. Some historians, however, describe it as more of an "expansion of West Germany," because it was "not a reunification of two equal states" (Ther 2019, p. 77).

The costs of the reunification "exceeded the forecasts considerably" (Görtemaker 2004, p. 768). As economists had predicted, purchasing power flowed out of the former GDR economy. Income disparities within the eastern parts of Germany grew ever wider. Although there were some beneficiaries of the reunification, there were a great many people who were now economically worse off. After 1990, social differences increased to a level that had been unknown in the GDR. The West German private sector contributed to the "economic decline" of the East. They refrained from investing. Capital flows from the West were almost non-existent. Therefore, more public resources were channeled to the East (Görtemaker 2004, p. 769). Privatization and deindustrialization processes took place, which benefited companies in West Germany. A central player in this radical privatization process was the "Treuhand agency," established to privatize the East German Volkseigene Betriebe (publicly owned enterprises). After the companies were privatized, only every fourth job remained (Böick 2018), and many felt that they had lost out in the transformation. This further fueled the discontent and disappointment of many East German citizens about the process of reunification.

These social changes were embedded in wider processes of global transformation. However, the process of winding-up the GDR proceeded at such a rapid pace that many people were no longer able to process them in their subjective experiences; nor were the political, cultural, and economic institutions able to do so. This led to experiences of anomie. The ways of life changed radically and very quickly. This can be seen from the rental costs. They rose to 20 times the levels of the GDR era, while incomes only doubled. All this led to a "fragmented development" (Land 2003) and to many social problems and frustrations among people socialized in the GDR.

Not only economically, but also with respect to the political, legal, educational and scientific institutions, East Germany was adapted to Western conditions. A unilateral transfer of elites and culture from West to East could be observed (Conze 2009, p. 780), which many people 
socialized in East Germany experienced as degradation and devaluation. The transformation processes were often perceived as a real "culture shock" (Wagner 1996). The unilateral transfer could also be observed with regard to the academic system (Kocka 1998, p. 7). The opportunities for a general restructuring were squandered. As far as sociology is concerned, there was a complete "unwinding of the structures of sociological research in the GDR" (Kaube 1998, p. 297; see also Schäfers 1993, p. 831).

One thing is certain: The reorganization of sociology and "the new appointments were carried out under West German rule" (Lepsius 2017g, p. 275). The commissions that decided on the future of sociology in East Germany were composed of sociologists from West Germany. They did not have much insight into sociology in the GDR. Some did not even consider the research of their colleagues from the GDR to be sociology, but considered it to be socialism. Although this might not have been intended, at the end of the transformation process sociologists from West Germany dominated the newly established institutes in the East. Apart from a few exceptions, there were hardly any GDR sociologists remaining (Lepsius 2017h [1993], p. 362). "Within three years, about 40 new professorships were established, a unique growth considering the 350 professorships in West Germany. After a phase in which the expansion of personnel in West Germany stagnated from about 1980 onwards, for many [sociologists] new career opportunities arose" (Lepsius 2017g, p. 275). But even 20 years after the fall of the Berlin Wall, in 2009, just fewer than $4 \%$ of the sociology professors were from the former GDR (Mau and Huschka 2010).

But back to 1990: Sociology in the GDR had attempted to reorganize and renew itself. As mentioned in Chap. 5, in February 1990, the 5th Congress of GDR sociology took place. Subsequently, a Gesellschaft für Soziologie (GfS, Society for Sociology) was founded (Schäfers 2016). At this time, it was clear that the GDR would be annexed to the FRG, but the conditions under which this would be done were not yet known (Meyer 1992, p. 5). There were hopes that GDR sociology would become an "equal partner" of West German sociology (Lepsius 2017h [1993], p. 334). In 1991, the GfS still organized a Soziologentag in Leipzig. It was a last, but futile attempt to promote East German sociology. The GfS disbanded in 1992. However, it still managed to found a sociological journal which is still one of the most renowned sociological journals in 
Germany, the Berliner Journal für Soziologie (Berlin Journal of Sociology) (Ettrich 2018).

Within three years, sociology in East Germany was re-established. It was recommended that the newly established professorships and institutes be structured in such a way that the fields of "theory, macrosociology, microsociology and methods" would be covered, preferably with one or two additional professorships for one of the special sociologies (Lepsius 2017 g, p. 276, 2017h [1993], pp. 340-34l). The first appointments to the professorships were made in 1992. Non-university research institutions that had employed the majority of sociologists were disbanded or reorganized (Lepsius 2017h [1993], pp. 336-337). The process of structuring sociology in East Germany was not without problems. For example, unequal gender relations established themselves here as well. "Of the 38 professors of sociology appointed in the new federal states until the end of 1993 [...] only 4 were women [...]” (Nickel 2006, p. 266).

\section{REFLECTIONS ON TRANSFORMATIONS IN THE SOCIAL SCIENCES}

Nobody thought that the GDR would collapse. In a project that I am conducting together with my colleagues Karl-Siegbert Rehberg $\left({ }^{*} 1943\right)$ and Joachim Fischer $\left({ }^{*} 1951\right)$ from Dresden, we interview older sociologists from German-speaking countries. At the end of the interview, we ask the following question: Which social processes were surprising for you despite your sociological expertise? The answer from respondents such as Thomas Luckmann, Peter L. Berger, Renate Mayntz and Ulrich Beck was unanimous: The most surprising event was the collapse of the GDR and of the Eastern Bloc. Sociology was completely unprepared for this (e.g., see Beck 1991). ${ }^{2}$

The social dynamics of the reunification were the driving force for new initiatives in the field of the social sciences (Krause and Ostner 2010; Schäfers 1996). The surprise and failure of sociology to foresee the collapse of the Eastern Bloc led to increased reflection and analysis. Sociological research on transformations began relatively soon after the reunification (Hauser 2010). This trend was promoted by the establishment of a Kommission für die Erforschung des sozialen und politischen Wandels in den

\footnotetext{
${ }^{2}$ Among the few exceptions who boast of having foreseen the collapse is Randall Collins (1995).
} 
neuen Bundesländern (KSPW, Commission for the Study of Social and Political Change in the New Federal States). This commission was to reorganize the East German research system. The establishment of a priority program of the Deutschen Forschungsgemeinschaft (DFG, German Research Foundation) titled "Social and Political Change in the Course of the Integration of the GDR Society" (Esser 2000, pp. 7-8) was central to this process. Numerous research projects on social change were conducted in this context. Other institutions such as the Wissenschaftszentrum Berlin (Berlin Social Science Center), the Max-Planck-Institut für Bildungsforschung (Max Planck Institute for Human Development), the Zentrum für Umfragen, Methoden und Analysen (ZUMA, Center for Surveys, Methods and Analyses) in Mannheim and the Demoskopische Institut (Demoscopic Institute) in Allensbach also contributed to the fact that empirical social research was intensified in an "incomparable manner" (Rehberg 2000, p. 14).

Everyone, including researchers from the East, had to venture into uncharted territory. It can be critically remarked that this was also a kind of "appropriation by research" (Rehberg 2000, p. 15). An equally extensive research program and transfer of financial and infrastructural means would also have been good for the old federal states, because there was still enough research to be done there (Rehberg 2000, p. 15).

Different perspectives and approaches could be observed in the sociological research of transformations (see, for the following summary, Joas and Kohli 1993a). The spectrum ranged from modernization theory (represented for example by Wolfgang Zapf (1937-2018)), ${ }^{3}$ systems theory (Detlef Pollack $\left({ }^{*} 1955\right)$ ), sociology of institutions (Wolfgang Schluchter), sociology of law (Bernhard Schäfers (*1939)), sociology of gender (Hildegard Nickel), sociology of social movements (Dieter Rucht $\left.\left({ }^{*} 1946\right)\right)$ to rational choice (Karl-Dieter Opp). For some, such as Detlef Pollack (1990), a sociologist of religion originally from East Germany, the collapse of the GDR was the result of a contradiction. According to him, the contradiction was that the GDR was on the one hand a modern, functionally differentiated industrial society, but on the other hand politically and ideologically undifferentiated and run by one party. Others like Wolfgang Zapf (1991, pp. 23-24) saw the theory of modernization confirmed. Since the GDR had lagged far behind in modernization, in

\footnotetext{
${ }^{3}$ Here I only mention a few names representing these approaches; of course, there were further individuals contributing to them.
} 
Zapf's eyes it was inevitable that it would collapse. Even Jürgen Habermas (1990), who was usually not a supporter of the theory of modernization, called this "a catching-up revolution" (nachbolende Revolution), with which the East was now normatively annexed to the Western democracies. For a short time, this view of the theory of modernization prevailed and experienced a brief comeback (not only in sociology, but in the public at large), after it had previously been abandoned in the course of the discourses on postmodernism. Francis Fukuyama's thesis of the "end of history" (Fukuyama 1992) became famous in this context.

There were also criticisms of these explanations for the collapse of the GDR. It was criticized that some theoretical concepts were not even considered in the analysis. According to Thomas Bulmahn (1996), there was initially a lack of concepts dealing with social inequalities and the German social structure. Gender relations were also ignored in research on the transformations (Nickel 2006, p. 271). Similarly, there were hardly any analyses of the effects of international processes. There was also a lack of "comparative analyses" comparing the transformation in Germany with other processes in Eastern and Central Europe (Bulmahn 1996, p. 25). These concepts, too, would have contributed toward an further explanation. But they were lost due to the hegemony of modernization theory and rational choice approaches. However, novel perspectives emerged as well. For instance, following the boom in the sociology of emotions that began in 1980 the effects of the "Wende" (a different term for the reunification) on the control of affects, the management of emotions, and the specific feeling cultures of East Germans (Neckel 1991) were analyzed. Other studies looked into the nostalgia for the time in the GDR the socalled Ostalgie (a word that blends "Osten", which is the German term for “eastern", and "nostalgia") (Neller 2006; Frevert 2020, pp. 285-288).

Because foreign policy factors, the regime's lack of resistance, and also the factor of historical contingency were neglected, the explanations often resembled teleological stories of progress, sacralized the people, or lapsed into a heroic narrative, according to which only the people of the GDR had brought about reunification, in a "revolution." In order to give more weight to foreign policy factors and the regime, Hans Joas and Martin Kohli (1993b, p. 9) more precisely referred to the transformation as a "collapse of the GDR" and not a "revolution" (Joas and Kohli 1993b, p. 9).

When it became obvious that theories of modernization and rational choice theories could not adequately explain the processes of upheaval and the crisis phenomena, the specific power relations, the historically 
contingent developments, the often one-sided cultural transfers, and the experience of disintegration associated with these processes, the attractiveness of alternative theories of social change increased. The focus of interest was not limited to the transformation of the GDR, but also included the larger processes of transition in Eastern Europe, transformations of the welfare states, and the process of European unification. In Germany, it was especially the "theory of reflexive modernization" of Ulrich Beck that was widely discussed in the course of the 1990s (Beck et al. 1994). The thesis was as follows: The processes of technological progress initiated by modern society and their secondary consequences fall back on society in a "reflexive" manner. The resulting uncertainty is further intensified by "thrusts of individualization" that radically change class affiliation, religious denominations, political divisions, work processes, and family relationships. The prevailing sociological picture of industrial society, Beck claimed, must therefore be redrawn. This means that modernity itself reacts with modernization mechanisms to the secondary consequences it brings about. In this context, "reflexive" means less the increase in conscious knowledge about the side effects and problems of modernization processes than ignorance of them, which is why Beck does not intend "reflexive" to be understood in the sense of conscious, intentional reflection (Beck et al. 1994, pp. 5-6), but rather in the sense of reflexive behavior, that is, the reactive attempts to control "latent side effects" (Beck et al. 1994, p. 5). Beck examined not only processes in Germany, but also called for greater consideration of global processes (Beck 1997). In his view, sociology was still focused far too much on nation states. According to Beck (2007), a sociology of the present, however, had to detach itself from national analyses and pursue a so-called methodological cosmopolitism, that is, to examine societies as globally interdependent entities.

Beck's theory of reflexive modernization and globalization was not the only theory postulating a new kind of modernity. In addition to this, very popular among sociologist at that time was Shmuel Eisenstadt's theory of multiple modernities, postcolonial studies, and Zygmunt Bauman's theory of postmodernism. However, with the turning away from the grand theories of Habermas and Luhmann, two major trends could be observed: a trend toward "special sociologies" or "hyphen-sociologies" ("Bindestrichsoziologien"), and a trend toward "diagnoses of contemporary society" ("Zeitdiagnosen"). In the GSA there are now 36 sections (research networks) for fields ranging from sociology of age and aging to 
sociology of law. Looking at the topics covered in leading sociological journals in Germany, the sociology of culture ${ }^{4}$ and the sociology of knowledge have experienced a boom, followed by the sociology of work, economy, and politics. As a result of this differentiation and specialization process, nowadays the so-called hyphen-sociologies often have their own journals. As the foundation of the Section for Qualitative Research shows, these differentiation processes were often the result of struggles within the sociological field. The section for Qualitative Research could not to be established until 2003, because there was strong resistance against it from the more quantitatively dominated GSA-section on "Methods of Empirical Social Research" (Ploder 2018, p. 751).

The topics of the booming diagnoses of contemporary society range from "risk society" (Beck 1986) to "experience society" (Schulze 1995), "knowledge society" (Stehr 1994), "fear society" (Bude 2014), "multioption society" (Gross 1994), or "society of decline" (Nachtwey 2016)to name but a few. Since the 1990s, these often one-sided diagnoses have been increasingly frequent and were presented in shorter intervals, fueled by demands for public sociology and promoted by a corresponding literature market that has made profitable use of these diagnoses. For politics, however, all the explanations of sociology have remained relatively inconsequential - with the exception of Ulrich Beck's "risk society", as we will see.

The boom and the rapid change in sociological diagnoses correlated with the social experiences of fragmentation, flexibilization, discontinuity, and disintegration. While the theories of Luhmann, Habermas, and Bourdieu were still characterized by the fact that they regarded society as a relatively stable system whose elements are not randomly associated, this now changed. As in other countries, in French sociology, for example (cf. Moebius and Peter 2004), in the 1990s, concepts such as social system, social field, or social totality were increasingly replaced by categories that focused on sub-aspects of what in the traditional concept of society was only relevant as a part of the whole. Now society was merely seen as a

\footnotetext{
${ }^{4}$ It should be noted that the sociology of culture or cultural sociology in Germany, both in terms of its tradition (Lichtblau 1996) and in the course of its revitalization by Friedrich Tenbruck, encompasses more than the analysis of culture in the narrower sense (music, literature, art, and theater), but also education, values, lifestyles, and so on, and above all theory (Moebius 2019; see also Chap. 4). At times, the section cultural sociology understood itself as the "true" theory section.
} 
"knowledge society," "experience society," or "information society." 5 Thus, these diagnoses often suggested that society is not a systematically structured, holistic entity. Sociological diagnoses replaced the theory of society. In contrast to previous theories, these diagnoses were characterized by the fact that they often made a very radical distinction between a before and after of the state of society and only emphasized individual aspects of society (cf. Osrecki 2011).

\section{Why Do We Need Sociology Today?}

The pluralization into many special sociologies ("hyphen-sociologies") was also a central aspect in a revived self-critical debate about the purpose of sociology. In the mid-1990s a series of articles appeared in the renowned weekly newspaper DIE ZEIT under the title Der Streit um die Soziologie ("The Dispute over Sociology"), which dealt with the role of sociology in society (see the articles in Fritz-Vannahme 1996). "Is there anything that sociology can contribute to contemporary German society?" "Why do politicians and the public today turn more to geneticists and brain researchers than to sociologists when seeking advice?" Questions like these were raised in the articles. Once again, sociology was perceived as being in crisis. The critical argument was that society had already disintegrated to such an extent that, in fact, it no longer existed: instead of society there were only individuals. This was reminiscent of the famous quote by Margaret Thatcher: "There is no such thing as society. There are individual men and women and there are families." In the debate in DIE ZEIT, the falling apart of sociology was diagnosed, too. Sociologists such as Dirk Kaesler, Ralf Dahrendorf, Hans-Peter Müller (*1951), Peter Wagner $\left({ }^{*} 1956\right)$, Gerhard Schulze (*1944), and Renate Mayntz reacted to the criticism, and Pierre Bourdieu also wrote an article. In response to the critique of sociology, some of the sociologists demanded a return to a greater social engagement of sociology. Sociology was said to be both a means of improving society and a troublemaker, drawing attention to social problems and revealing hidden power relations. Moreover, some authors argued, it was perhaps not sociology that was in crisis, but the general idea of science in society, which increasingly relied only on mathematicized scientific products. Many people would wish that sociology

\footnotetext{
${ }^{5}$ In a certain manner, the concept of "world society" by Rudolf Stichweh (2000) is one exception here.
} 
would provide invariant insights, but as society is dynamic, this maybe is impossible. "The scientific paradigm is indestructible; one finds this attitude even in academic sociology itself. One reduces 'variance,' plays around with systems of equations, falsifies, correlates, quantifies, and is not bothered by the fact that the social dynamics repeatedly cause the laboriously erected models to collapse. The longing for mathematically supported analyzability is stronger than common sense" (Schulze 1996, pp. 54-55).

\section{The Gender Turn in Feminist Sociology}

With regard to the sociology of gender in Germany, it is noteworthy that, with the exception of Marxism, early Critical Theory, and the theory of reflexive modernization, it was hardly influenced by the grand theories from Germany. There are, for example, only very few who pursue a sociology of gender with systems theory or explanatory sociology. There isn't even a sociology of gender that is based on Habermas, as Nancy Fraser's ( $\left.{ }^{*} 1947\right)$ theory is. Instead, the sociology of gender was often inspired by Bourdieu, Foucault, Harold Garfinkel, or, since the 1990s, Judith Butler.

Around 1990, there were major transformations and debates in feminist sociology (see in detail Hark 2005, pp. 269-332; Paulitz 2019, pp. 395-406). Feminist sociology experienced a deconstructivist turn, caused by the publication of Judith Butler's Gender Trouble (1990). Because of the German translation of the title as Das Unbehagen der Geschlechter (1991, literally translates back to English as "The Uneasiness of Gender"), many thought the book was a critique of feminism and not, as Butler emphasized, a contribution to feminist theory (Hark 2005, p. 269). The debate within feminist sociology revolved around the "relationship between the nature and culture of gender" (Paulitz 2019, p. 395), because Butler, following Michel Foucault, made the argument that every description of nature is culturally mediated-there can be no "pure," precultural description of sex and gender. Many accused Butler of neglecting the body and materiality. Even when Butler reacted with Bodies That Matter (1997) and indeed attributed a major role to materiality, this elaboration of her approach was mostly lost in the tangle of voices. She was also accused of destroying the politics of feminism by dissolving the category of "woman." The political discourse that prevailed in Germany when Butler's books were published was totally different from the one in the United States. As Tanja Paulitz (2019, p. 402) points out, while in the 
United States there were already "critical discussions of identity politics" and of questions of racism and the exclusion of black and lesbian women, in Germany such discussions were more likely to be held in left-wing autonomist circles outside the universities. This also changed with Butler.

Despite the initially critical, often even hateful attitudes against Butler, feminist sociology changed lastingly as a result of the reception of her work. To this day, Butler remains an important point of reference in feminist and sociological debates in Germany (cf. Villa Brasvlasky 2020). Foucault, whom Butler referred to in her argumentation, has now been received even more in sociology. Butler was therefore not only important for feminist sociology, but also for the field of sociological theory: she was regarded not only as a feminist but also as a poststructuralist theorist and contributed to the boom of poststructuralism (Moebius and Reckwitz 2008). This boom of poststructuralism in Germany was also related to a new generation entering the sociological field. This new generation no longer followed Habermas in his exaggerated criticism of French intellectuals (Habermas 1985), but wanted to reconcile the two camps that stood in opposition to each other in Germany; these were the camps of Critical Theory and poststructuralism. In the 1990s, there was a younger generation of sociologists who increasingly studied Foucault, Jacques Derrida (1930-2004), and Butler, and this to contribute to a critical sociology. In sociology, these developments also resulted in the establishment of a "poststructuralist social science" (Stäheli 2000; Moebius 2003; Moebius and Reckwitz 2008).

The debate over Butler brought about many changes in feminist sociology. The term "women's studies" was increasingly being dropped as new terminological notions such as "gender studies" or "sociology of gender" (Paulitz 2019, pp. 398-406) arose. Feminist sociology was increasingly able to show that all areas of society are always gendered. Furthermore, the focus was no longer only on women, with research on masculinities being increasingly carried out. Gender was no longer primarily understood as a structural category, but as a "process category" (Paulitz 2019, p. 396). There was the general question about how gender is produced and reproduced. To what extent have our ideas about the nature of sex always been cultural ideas? How can we talk about nature if speaking is always already an effect of a cultural discourse? And how do the ideas of sex and gender relate to our ideas of (hetero-)sexuality? Based on questions like these, the inclusion of the category of sexuality in the analysis of gender relations was also central. However, the shift from the 
category of "woman" to the general category of "gender" was not without criticism, because of the fear that the still existing "masculine domination" (Bourdieu 1998) over women would be lost of sight (cf. Fleig 2014).

In the feminist field, differentiations and splits into different camps, different positions ranging from essentialism to constructivism, increased. The constructivist reading was further enhanced by the fact that, almost parallel to Butler's books, Candace West and Don H. Zimmerman's (1987) approach of "doing gender" was promulgated in Germany by the feminist researchers Regine Gildemeister $\left({ }^{*} 1949\right)$ and Angelika Wetterer (*1949) (Gildemeister and Wetterer 1992; see also Paulitz 2019, pp. 400-401). ${ }^{6}$ With their contribution they also called attention to the delayed reception of the earlier writings of Carol Hagemann-White, who had attempted to bring the "doing gender" approach into the German discussion already in the mid-1980s (Hagemann-White 1984). This approach was, among others, inspired by microsociological studies of Harold Garfinkel and Erving Goffman. Garfinkel's ethnomethodological approach was applied to questions of gender already in 1978 in an influential study published by the American sociologists Suzanne J. Kessler (*1946) and Wendy McKenna (*1945) (Kessler and McKenna 1978). This study, then, played a crucial role for the adaption of the microsociological idea of "doing gender" in Germany.

According to Tanja Paulitz, who is currently analyzing the history of feminist sociology in Germany in more detail, the debate on Butler "favored" the reception of the constructivist "doing gender" approach (Paulitz 2019, p. 401). The concept of "doing gender" tried to establish itself in the field of feminist sociology as a counter position to Butler. Butler's approach was accused of being "non-sociological," whereas it was claimed that the approach of "doing gender" was (Paulitz 2019, pp. 403-404). The accusation of not being sociological and of being out of touch with reality was in turn used by other positions in the field of feminist sociology against the approach of “doing gender" (Paulitz 2019, pp. 405-406).

However, the struggle for interpretive power eventually led to a "victory" of "doing gender" and Butler. Further differentiations took place, which also had an institutional impact (Paulitz 2019, pp. 407-411), for example, in the establishment of study programs in gender studies.

\footnotetext{
${ }^{6}$ I would like to thank Tanja Paulitz for helpful remarks on the "doing gender" approach and for comments on this section on the gender turn in general.
} 
While gender studies and gay/lesbian studies had previously been rather separate, due to the reception of Butler's theory they were now often combined as queer studies. The relations between feminist sociology, gender studies, and queer studies are, however, diverse. Sometimes there are close relations between the approaches, sometimes they engage in "boundary work" (Gieryn). In contrast to gender studies, however, queer studies has so far not been able to institutionalize itself at universities in the form of chairs in Germany.

The current trend, however, is toward analyses of intersectionality, that is, on analyses of the intersection especially of gender, class, "race", and sexuality (Paulitz 2019, p. 410). Intersectionality, a concept that has been discussed for some time already in other countries, is considered the new paradigm in feminist theory in Germany.

Gender studies have successfully established themselves in the academic field. However, for some years now they have been confronted with fierce attacks (Paulitz 2019, pp. 410-411). In particular, the right-wing populist movements, currently observable in Europe and the USA, have intensified the attacks on gender and queer studies. The attacks are not only directed against gender studies alone, though. They concern feminism and the demands for sexual self-determination in general. Instead of looking for the causes of the processes of social disorientation, the fears of social relegation, and the cultural insecurities associated with the economic and political actors and structures, these are again projected onto women, strangers, and minorities. Anti-intellectualism, anti-feminism, and sexism have become socially acceptable again in Germany, as in many other countries.

\section{The Reception of New Theories of Capitalism}

In the 1990s, one of the most pressing social problems of the Federal Republic of Germany was high unemployment. At the beginning of 1994, almost four million people were unemployed, and the unemployment rate was around $10 \% .{ }^{7}$ Unemployment was caused not only by the process of reunification, but also by economic globalization (Görtemaker 2009, pp. 101-105). When the Kohl government was re-elected by a narrow

\footnotetext{
${ }^{7}$ See the Statistics of the Federal Employment Agency https://statistik.arbeitsagentur.de/DE/ Navigation/Statistiken/Fachstatistiken/Arbeitsuche-Arbeitslosigkeit-Unterbeschaeftigung/ Produkte/Zeitreihen-Arbeitslose-Arbeitsuchende-Arbeitslosenquoten/Zeitreihen-ArbeitsloseArbeitsuchende-Arbeitslosenquoten-Nav.html (accessed April 30, 2020).
} 
majority in 1994, it attempted to solve these problems with neo-liberal measures such as "reducing continuation of payments in the case of sick leave, lifting protection against dismissal for companies with no more than ten employees and raising the retirement age, or cutting unemployment benefits" (Görtemaker 2009, p. 104). In East Germany there were processes of anomie and disintegration. The social inequalities aggravated the general discontent. Hopes that living conditions in East Germany would improve immediately were betrayed. The "flourishing landscapes" in the East, promised by Helmut Kohl, failed to appear.

As a result of this, a growing interest in theories of capitalism developed in Germany. These theories were not so much systematic economic analyses but focussed on cultural processes. Examples of these newer approaches included works such as Richard Sennett's The Corrosion of Character (1998) or Luc Boltanski (*1940) and Ève Chiapello's (*1965) Le Nouvel Esprit du Capitalisme (1999; The New Spirit of Capitalism). This cultural perspective on anomie and cultural disorientation was also related to the fact that capitalism now had a different effect than previously. As Lothar Peter (2009) has pointed out, theories of capitalism before the 1990s, as, for example, Marcuse's One-Dimensional Man (1964), emphasized the socially integrative function in the apparatus of power. Although it led to alienation and disillusionment, capitalism was thought to have a socially inclusive effect. In contrast, after 1990 new mechanisms of capitalism were identified that had exactly the opposite effect. Instead of over-integration into capitalist society, it was now argued, the current dynamics of capitalism lead to new social divisions, structural unemployment, and experiences of disintegration. The concept of class society therefore reappeared in sociological debates. Likewise, the analysis of elites became increasingly important (Hartmann 1996, 2002; Krais and Hartmann 2001). The concept of a classless or socially leveled society was no longer discussed.

\section{Key Social Problems in the Early 1990s: Unemployment, Poverty, Right-Wing Extremism, AND RaCISM}

The concept of "poverty" also returned to the public and sociological debate (Schildt and Siegfried 2009, pp. 481-482; Honneth 1994). The special issue 32 of the Cologne Journal of Sociology and Social Psychology (KZfSS) may be regarded as an indication and reaction: In 1992, it was 
devoted to "Poverty in the modern welfare state." "Poverty despite prosperity" (Bohle 1997), that was the finding. Poverty was understood in terms of deprivation and as "a blatant lack of means to participate in 'normal' social life" (Bohle 1997, p. 129). Especially at the end of the 1990s, research on precarity and social exclusion increased. Exclusion is still a topic that is relevant today, particularly with regard to the ongoing social problems in East Germany, which are a breeding ground for rightwing populism (Bude and Willisch 2007).

However, the trend of social erosion and exclusion affected not only Germany. It was not only a consequence of the reunification, but was generally observable in capitalist societies. In European societies, the "endangerment of the social in highly developed capitalism" (Kronauer 2010) was often already virulent before the fall of the Iron Curtain. What was new, however, was the prominence of the terms "exclusion" and "precarity" for the sociological description of these processes. ${ }^{8}$ In Germany, in particular those analyses that had been initiated in France since the mid-1990s, for example, Robert Castel's (1933-2013) Les métamorphoses de la question sociale (Castel 1999; cf. Castel and Dörre 2009), were considered and further developed.

Particular structural problems in East Germany were poverty and unemployment. For the majority of East Germans, soon after the euphoria over the reunification, feelings of heteronomy, rootlessness, disillusionment, and "cultural devaluation" (Conze 2009, p. 748) began to spread. In the face of a society perceived as "cold," many longed for a "warm" community. In many cases this longing gave rise to backward-looking projections that emphasized the communal character of living together in the GDR. Added to this were fears of strangers. The aggressions were mainly directed against asylum seekers, foreigners, strangers, disabled people, leftists, minorities in general, and also against politicians. At the beginning of the 1990s, extremely violent racist attacks by neo-Nazis on asylum seekers began in the East, often fueled and supported by several thousand sympathizers-sometimes even catered by mobile snack stalls (Prenzel 2017).

Right-wing extremist violence and its approval by the population increased drastically since 1991 (Herbert 2014, pp. 1173-1178). The

\footnotetext{
${ }^{8}$ In this context, a narrow definition of exclusion in accordance with systems theory was explicitly opposed. In systems theory, exclusion merely means falling out of functional systems and is not associated with social inequality.
} 
introduction of new, neo-liberal labor and social policy measures further stoked fears of social relegation. This fear led to a search for security, which was expressed partly in renationalisation tendencies and xenophobia. Debates about identity and the dominant culture arose. The fears were structural. This was shown very clearly, for example, in the studies carried out by Wilhelm Heitmeyer ( $\left.{ }^{*} 1945\right)$, which were published every year with the title Deutsche Zustände ("German Conditions"). ${ }^{9}$ According to Heitmeyer and his team, one of the most significant disintegration experiences seven years after the "Wende" was the "increasingly deepening splitting apart of two German societies". Despite the so-called "elevator effect", a term introduced by Ulrich Beck (1986, pp. 121-160) to describe the increase in material prosperity, there was an empirically measurable "intensification of social inequality," the "exclusion of social groups and milieus from access to material and cultural goods," cutbacks in institutions of the welfare state and infrastructure, discrimination of minorities, "fragmentation of life contexts," and the "dissolution of the basic consensus on values and norms" (Heitmeyer 1997, pp. 10-11).

\section{The Red-Green Government and the Political Challenges Around 2000}

High unemployment was one of the main reasons for the change of government in 1998 and the end of the "Kohl era." After 16 years, voters not only considered the government of Chancellor Kohl to be worn out, they also no longer trusted that he could resolve the high national debt and unemployment. The chancellor who succeeded Kohl in 1998 was Gerhard Schröder from the Social Democratic Party (SPD). He formed a coalition with the Green Party (see in detail Wolfrum 2013). This was possible, on the one hand, because the Greens enjoyed great popular support for their environmental policy and, on the other hand, because their profile increasingly tended toward economic liberalism. The majority of the Greens now stood "for a policy of flexibilization and deregulation as well as a reorganization of social security systems" (Conze 2009, p. 802). This coincided with Schröder's ideas, which were based on Anthony Giddens' (*1938) and Ulrich Beck's idea of the so-called Third Way (Wolfrum 2013, pp. 138-162).

\footnotetext{
${ }^{9}$ These investigations are based on analytical concepts of the classical theories of anomie of Émile Durkheim and Robert K. Merton (Heitmeyer 1997, p. 13).
} 
In addition to high unemployment, the dismantling of social security systems, and an ecological tax reform, the domestic agenda of the redgreen coalition included the phasing out of nuclear power and the reform of citizenship laws (see Herbert 2014, p. 1221; Görtemaker 2009, p. 112). In terms of foreign policy, the "Kosovo conflict" posed the greatest challenge to the coalition. There was no uniform approach by the UN. NATO "agreed to threaten to launch air strikes against Serbia" (Görtemaker 2009 , p. 116). The participation of Germany was increasingly demanded. The new government, including the formerly pacifist Greens, finally agreed to the demands for participation in the NATO mission. A refusal by the Greens would have made the continuation of their coalition with the SPD unlikely; the only party in the Bundestag that voted against a participation was the Partei des Demokratischen Sozialismus (PDS, Party of Democratic Socialism, today: Die Linke, literally The Left). "It was the first combat mission of German armed forces since World War II-ordered, ironically, by a red-green coalition government, and without a clear UN mandate." (Görtemaker 2009, p. 118)

The attacks by radical Islamist terrorists on September 11, 2001, on the World Trade Center in New York and the Pentagon in Washington, marked another crucial historical turning point. It seemed that the geopolitical conflicts were now again being fueled far more by religious and cultural differences than had been the case during the Cold War. As a result, the perception of the political role of religion increased in many areas of society; in the social sciences in Germany, too, there was a renaissance of the sociology of religion (cf. Pollack 2015, p. 435).

In the 2002 elections to the German Bundestag, the red-green government was again victorious. It was a narrow victory. Chancellor Schröder was able to convince the voters of his merits, because he took a clear stance against German participation in the war in Iraq and because he was able to present himself well publicly and perform better in the media than his opponents (Wolfrum 2013, pp. 410-497). All this took place in an ongoing global process accelerated by the digitalization of communication, which was described as the new post-industrial economic form of digital financial-market capitalism, the New Economy (Conze 2009 , p. 823). Since 2003 , the neo-liberal reforms of labor market policy, that the red-green government implemented, the "Agenda 2010" and the so-called Hartz concept, ${ }^{10}$ became effective. Over four million people

\footnotetext{
${ }^{10}$ The new labor market reforms of the red-green government, that were implemented since 2003, were called "Hartz" concepts after their "inventor," the Volkswagen manager Peter Hartz.
} 
were unemployed around 2003. The aim of the reforms was to reduce unemployment till 2005 by two million (Wolfrum 2013, p. 528). The so-called Agenda 2010, which chancellor Schröder presented in 2003, was also in line with the general trend of the New Economy. The "Agenda 2010" meant, among other things, that after one year unemployed people would receive as little money as those living on social welfare (Sozialhilfe), but only on the condition that they were willing to accept any job (Fülberth 2012 , p. 104). ${ }^{11}$ The results of this change, however, were further processes of disintegration; in particular, stigmatization and prejudice against the long-term unemployed increased, also the proportion of poor people has risen, while at the same time the concentration of capital grew (Hartmann 2010, pp. 272-273). Sociologists even spoke of a "class struggle from above" in which the elites "deliberately" promoted "social disintegration" (Hartmann 2010, 2013). Relaxations in the protection against dismissal and many other measures such as the cuts in social security and unemployment benefits led to large protests, among others by trade unions as well as by the globalization-critical movement Attac (Wolfrum 2013, pp. 528-583).

How are the reforms and deregulation of the labor market to be assessed? Depending on the ideological orientation, this is of course judged differently. Economic sociologists at any rate spoke of a "successful failure" (Dörre 2010). From this perspective, the successes invoked by the proponents of the reforms are more likely to be the result of statistical adjustments and of the "expansion of insecure employment conditions" (Dörre 2010, p. 297).

The processes of the New Economy also had an impact on sociology in Germany: Research on the new dynamics of capitalism (Beckert 2016) and economic individualization emerged, which, for example, led to new concepts in the sociology of work, in economic sociology, and in the sociology of culture. The term "Entrepreneurial Self" (Bröckling 2016 [2007]) was now frequently referred to. According to the diagnosis, everyone was now increasingly responsible for her or his own fortune and had to manage her/his life like a project or enterprise (Dörre 2010, p. 295). In contrast to the United States, this was rather unusual for the

${ }^{11}$ Before the "Agenda 2010", unemployment benefit and social welfare were more separated; depending on age, one could receive unemployment benefit for up to three years. Now, in the year 2020, the standard rate of unemployment benefit ("Arbeitslosengeld II") is 432 euros per month for a single person. 
people in Germany and was not anchored in the German mentality. For those who were the beneficiaries of the new economic and social structures, individualization often meant an expressive individualism and an increasing self-fulfillment. Those who were not up to these new processes were considered as losers and were now held personally responsible for their failure (Ehrenberg 1998). What was new was that those affected internalized this individualizing perspective and did not blame the state for their structural disadvantage, but themselves (Bröckling et al. 2000; Bröckling 2016 [2007]).

In the mid-2000s, the education system and education policy also moved back into the focus of political attention. In 1999, the so-called Bologna Process was started, an attempt to unify and facilitate the comparability of higher education standards in Europe. However, as in other countries, the universities in Germany were not well prepared for this; there was a lack of personnel and school-like teaching, application-oriented training increased, and teaching of fundamentals and individual academic freedom declined (Schultheis et al. 2008; Lenzen 2014). Instead of standardization, each university now sought to distinguish itself in the competition for students with its own profile, wherever possible. Ultimately, however, these reforms led to a provincialization rather than to a nationwide or European integration of higher education (Nida-Rümelin 2010, p. 135). As a result, a distinctive feature of higher education in Germany, the Humboldt style university, where one could conduct research free from market constraints, was in even more danger than it already was before. $^{12}$

Similar to the labor market reforms, attempts were now made to orient all educational institutions toward employability (Sambale et al. 2008; Münch 2014). Science and education were now increasingly viewed from the perspective of their immediate usability (Münch 2009) and the universities were transformed into "enterprises" or "entrepreneurial universities" (Münch 2014, p. 246). ${ }^{13}$ The reform of the universities led in Germany,

\footnotetext{
${ }^{12}$ See, for example, the discussions and articles by Ulrich Beck, Judith Butler, Dirk Baecker (*1955), Simon Critchley (*1960), Anselm Haverkamp (*1943), Julian Nida-Rümelin ( $\left.{ }^{*} 1954\right)$, Alex Demirović ( $\left.{ }^{*} 1952\right)$, and others in Horst et al. (2010), also Schultheis et al. (2008), Lenzen (2014).

${ }^{13}$ This applied not only to universities, but also to schools. The PISA tests ("Programme for International Student Assessment"), comparative achievement tests that revealed the emerging preference for rankings, also contributed to this. Richard Münch (2009, p. 39) points out that education today is reduced to human capital that is primarily oriented on
} 
among others things, to new salary structures, to the introduction of junior professorships, to the limitation of temporary positions to 12 years, ${ }^{14}$ and to the so-called Excellence Initiative, a competition between universities aimed at providing a few "top" universities with particularly good financial resources and funding. Although the structural conditions were completely different from those in the United States, the Ivy League universities served as the dominant role model (Münch 2007).

Just a few words about junior professorships: In order to get a professorship at a university in Germany, academics still usually have to write a habilitation thesis (in sociology usually a "second book" written after the doctoral thesis, more recently, it can also be a cumulative habilitation thesis consisting of already published journal articles and a framing introduction) and go through an appointment procedure. ${ }^{15}$ This consists of a lecture, discussion, and an internal interview with an appointment committee (Berufungskommission). Since 2002, it has been possible to obtain the qualification for a professorship through a junior professorship instead of the habilitation thesis. The junior professorship is limited to six years. When the junior professorships were set up, it was originally planned that all of them would have a tenure track option and, following an evaluation, would lead to a regular professorship. In reality, however, this option is only available for a few of the positions. With the introduction of the junior professorship, there are now three different types of professorships and payments: chair professorships (salary scale W3), professorships (W2), ${ }^{16}$ and junior professorships (W1). The payment varies slightly depending on the federal state. Before the W-salary scale there was the C-salary scale, which was a little higher. ${ }^{17}$

"usable competences". In comparison with other countries, the PISA tests revealed educational deficits and unequally distributed opportunities in Germany. The resulting "PISA shock" triggered a dynamic of reform measures.

${ }^{14}$ This law is called "Wissenschaftszeitvertragsgesetz" (Fixed-term employment contracts for researchers). After the 12 years, the university must either take over the employees indefinitely or dismiss them. In most cases, the universities decide to dismiss, so that many post-docs have to leave academia.

${ }^{15} \mathrm{~A}$ detailed description of the German academic career structure can be found on the following website: https://www.eui.eu/ProgrammesAndFellowships/AcademicCareers Observatory/AcademicCareersbyCountry/Germany (accessed October 7, 2020).

${ }^{16}$ There are no chairs at the universities of applied sciences (Fachbochschulen), the professorships there have the salary scale W2.

${ }^{17} \mathrm{~A} \mathrm{W1}$ gross salary is on average about 4800 Euro, a W2 6300 Euro, and W3 7300 Euro. Since the professors are usually civil servants, they pay less tax. Thus, for example, a W3 net 


\section{Sociology and National Socialism: New Debates AND NEW RESEARCH}

The 1990s and 2000s were also a time of intense public debate about the Nazi past. This could also be observed in sociology. Two phases can be distinguished, one in the 1990s and one after 2010. ${ }^{18}$ Since the late 1980s, more detailed research on sociology under National Socialism has been conducted in West Germany. Otthein Rammstedt (1986) examined the constitution of a genuine "German sociology" under National Socialism (referring in particular to Hans Freyer, Andreas Walther, Gunther Ipsen, Max Hildebert Boehm, Max Rumpf, Werner Sombart, Othmar Spann, and others). In addition to Rammstedt's book, it was in particular the work of Carsten Klingemann (1986, 1992, 1996, 2009) that revealed in great detail the entanglements of sociology with the Nazi regime. Klingemann's book Soziologie im Dritten Reich (1996, Sociology in the Third Reich) led to numerous controversies. Some criticized that empirical social research, but not sociology as an academic discipline, persisted during the Nazi regime. Others saw sociologists like Leopold von Wiese wrongly condemned by Klingemann (see for the discussions van Dyk and Schauer 2015, pp. 165-166). And still others were critical of Klingemann's and Rammstedt's theses, which claimed that after 1945 there was much continuity of sociology with the Third Reich. As Klingemann showed, there was no absolute new beginning of sociology in Germany after 1945, as had been claimed, for instance, by Leopold von Wiese. Instead, there were numerous continuities. The merit of Klingemann's and Rammstedt's studies was that they provided new analyses of the role of sociology and social research in the Nazi era, which finally dispelled the myth that there had been no sociology and social research during that time.

The Hamburger Institut für Sozialforschung (Hamburg Institute for Social Research), founded in 1984 by Jan Philipp Reemtsma (*1952), sparked off a major debate. In an exhibition in 1995, the Institute showed the war crimes of the German Wehrmacht between 1941 and 1944. The public was polarized, neo-Nazis marched through the streets, riots broke out, the Bundestag debated very emotionally. Yet the core thesis of the

salary is about 5700 Euros per month, a W2 5200 Euro and W1 4400, calculated with two children and being married (see the calculator on: https://oeffentlicher-dienst.info/ beamte/bund, accessed April 30, 2020).

${ }^{18}$ As mentioned in Chap. 2, earlier analyses were provided by Svend Riemer (1932), Heinz Maus (1959), and Ralf Dahrendorf (1965). 
exhibition was well documented; a specially founded commission of historians also confirmed the thesis: The Wehrmacht, that is, the regular German army, and not only the SS, had been actively involved in the war of extermination at the Eastern Front and in the mass murder of Jews, Romani, and other civilians as well as of prisoners of war.

After 2010, the sociological field underwent another phase of historical reappraisal, as evidenced, for example, by the volume Soziologie und Nationalsozialismus (2014, Sociology and National Socialism) edited by Michaela Christ and Maja Suderland. For too long, sociology had hardly ever dealt with the Nazi regime, leaving this to historians. Especially in Germany, more would have been expected from sociologists on this point. The question arose why National Socialism was "neglected" as an "object of sociology" (van Dyk and Schauer 2015, p. 168). Some answers to this question have been given: After the war one wanted to look ahead and quickly forget the past, like, as we have seen in Chap. 3, Leopold von Wiese for example.

\section{Current Trends and Debates}

Sociology holds a solid position in the academic field in Germany. It is represented by two professional organizations, the GSA and the Berufsverband deutscher Soziologinnen und Soziologen (Professional Association of German Sociologists), as well as by numerous journals, and is firmly established at most universities (Meja et al. 1987, p. 2). Looking at the number of students, there was a phase of expansion until the mid-1970s, a phase of stagnation in the 1980s, and again an expansion in the 1990s (Stockmann 2002, p. 239). While the number of first-year students in sociology was 2500 in 1988, the number rose again in the 1990s and even doubled in 1999 to over 5000 (Meyer 2002, p. 110). The proportion of women also increased, with an increase of over $60 \%$ for the same period. If students taking sociology as a minor are also included, the total number of students also almost doubled from 10,000 in 1988 to 19,000 in 1999 (Meyer 2002, p. 110), which can among others be explained by the growing interest in sociology following the German reunification (Meyer 2002, p. 61). In the 1990s, sociology was one of the most popular subjects (Meyer 2002, p. 62); however when compared to other subjects, it took longer for graduates to get a job (Meyer 2002, pp. 88-109). But these difficulties have decreased. Particularly in the private sector, graduates get jobs (Meyer 2002, p. 111; Behrendt et al. 2002, 
p. 191). ${ }^{19}$ Overall, the jobs range from more sociology-related such as empirical social research and opinion research to political consulting, education, journalism, social work, healthcare, human resources, administration, and so on (cf. Breger and Böhmer 2007). But here, sociologists are in increasing competition especially with other social scientists like economists, political scientists, and lawyers.

Sociology as academic discipline is still facing another problem: As in other disciplines, many students inscribe themselves in sociology, but a considerable number, almost a quarter, drop out at some point. In addition, there have been large cutbacks in personnel and resources. With the "Aufbau Ost" there was a brief growth, but since the mid-1990s there has been a decline in the number of professorships. This has led to a poor student-to-staff ratio, with an average of 70 students per professor (Stockmann 2002 , p. 244). Financial resources have flowed particularly into the life sciences or computer science, which have a strong position in the academic field and also enjoy a better image in society because they appear more useful and "more profitable" (Meyer 2002, pp. 111-112).

Sociology in Germany is also in active exchange with sociological actors from other countries, participating in both the ESA (European Sociological Association) and the ISA (International Sociological Association); some sociologists are also involved in the ASA (American Sociological Association). It is therefore only natural that it is influenced by international trends and participates in them. This applies, for example, to current discussions about public sociology or the sociology of emotions, but also, in the theoretical field, to discussions about networks or the limits of the social. In the theoretical field of sociology in Germany there is a wide variety of approaches, ranging from rational choice, neo-institutionalism, systems theory, Critical Theory, social philosophy, social criticism,

${ }^{19}$ As Kreckel (2013, pp. 217-220) shows, the number of students of social science disciplines grew until 2003, but then declined slightly. At the same time, there was a trend in the professorships in the opposite direction. These became fewer. Instead, fixed-term positions below the professorial level were expanded. According to the statistics of the Federal Statistical Office, there were 19,566 sociology students in the winter semester $2018 / 2019,63 \%$ of these were female. Since 2002, the total number of students in Germany has been around two million, while the number of sociology students has been around $1 \%$. Source: Statistisches Bundesamt (Destatis), Fachserie 11, Reihe 4.1. https://www. statistischebibliothek.de/mir/receive/DEHeft_mods_00110047 (Access: May 10, 2020). 
neo-pragmatism, ethnomethodology, feminist sociology, philosophical anthropology, theory of reflexive modernization, historical sociology, theory of practice to poststructuralist concepts such as governmentality studies.

However, grand theories made in Germany-as were developed in the 1980s - are now hardly to be found (Lepenies 1997, pp. 61, 93). Important exceptions, which are also known internationally, are the theory of reflexive modernization of Ulrich Beck and the neo-pragmatism of Hans Joas, who is today, one of the internationally most renowned living sociologist from Germany. Indeed, theories are still a central element of sociology in Germany today and are still held in high esteem in accordance with the German sociological tradition. The aforementioned trend toward Zeitdiagnosen (diagnoses of contemporary society) continues (cf. Osrecki 2018). These interpretations, diagnoses, and forms of problematization of the present are even more prevalent than in the past. It is true that this type of sociological diagnosis and public sociology also existed in Germany in the past; consider for example books by Hans Freyer (1955, 1965), Helmut Schelsky (1957, 1965, pp. 391-480, 1977 [1975]), or Ulrich Beck (1986) (cf. Lichtblau 2017 [1991]; Kruse 1994). But at present, the sociological interpretations offered on the book market change every few months at an ever-faster pace. This may perhaps be related to the perception that society itself is accelerating more and more (Rosa 2013) -although that too is just one interpretation among many. It was only yesterday that we lived in a "risk society" (Beck 1986), now we are living in the "society of acceleration" (Rosa 2013). Whereas yesterday it was the "postmodern multi-option society" (Gross 1994) and the "experience society" (Schulze 1995), now it is the "society of decline" (Nachtwey 2016), the "society of fear" (Bude 2014), or the "society of singularities" (Reckwitz 2017) in which we find ourselves. One of the few scholars who are currently working toward a new general theory of society again is Uwe Schimank (*1955) from Bremen, who in recent publications attempts to describe society as a systematic social context (Schimank 2013, 2015).

The trend toward diagnoses of contemporary society is accompanied by a "return of the author" (Lepenies 1997, pp. 94-100). The focus on single persons or individuals that can be observed everywhere today, especially in politics or economic theory-an expression of individualization-is also evident in the current market of sociological 
commodities. ${ }^{20}$ Individual star authors and their diagnoses of contemporary society-also as a consequence of the "Matthew Effect" (Merton 1968)_ are gaining more and more attention than constant theoretical patterns and concepts, who develop a systematic theory of society or the social as a whole, like the theory of Bourdieu did it for example.

Because of the boom of "studies," nowadays there are frequently situations of competition among these new interdisciplinary alliances. For instance, science studies, queer studies, or visual studies break down the boundaries of the sociological field and develop more interdisciplinary perspectives - in more or less productive ways. In addition, there are generation-specific trends and field dynamics: While in my student days, the time around 2000, poststructuralism (Stäheli 2000; Moebius 2003) was the most popular theoretical approach for younger scholars, nowadays the theories of Gilles Deleuze (1925-1995), Bruno Latour (*1947), or Donna Haraway (*1944) are preferred (cf. Fischer and Moebius 2014).

In recent decades, sociology in Germany has come ever closer to the globally prevailing understanding of sociology as an empirically operating social science and has also contributed to this global mainstream of sociology. This means that a distinctive German sociology can be observed less and less. Still, one can perhaps identify some specific characteristics of German sociology, which, of course, may also be found in one form or another or with other accentuations in other countries. ${ }^{21}$ These are related to its tradition, to the specific social processes in Germany, and to related inner-academic developments. To me, the characteristics of sociology in Germany seem to be, firstly, its affinity for theory, or rather, the great significance of historically and philosophically informed theory (see also Meja et al. 1987, p. 3). The theoretical landscape is quite diverse (Fischer and Moebius 2019) and "cannot be reduced to two ideological axes (conservative and critical traditions)" (Müller 1989, p. 321; see also Meja et al. 1987).

Secondly, as far as empirical social research is concerned, there is also a connection to philosophy. The focus in Germany is more often on the philosophical reflection on empirical research, that is, on methodology,

\footnotetext{
${ }^{20}$ According to Wolf Lepenies (1997, pp. 94-100), in the United States and France the author's return expresses itself through autobiographies, in which he sees rather positive signs of knowledge transfer and considers them currently to be the "best textbooks" (Lepenies 1997, p. 94).

${ }^{21}$ On the question of national traditions in the social sciences see Heilbron $(2008,2015$, pp. 218-223).
} 
than it is, for example, in the United States, where more emphasis is placed on research practice. At the same time, a greater abstinence from participation in the direct political realm can be observed in Germany due to the value judgment debates and the implementation of the understanding of sociology of the Cologne School, while in the United States, for example, there is greater emphasis on the direct political relevance of research (cf. Bethmann and Niermann 2015). ${ }^{22}$

Thirdly, to this day, German sociology still lacks self-confidence with respect to US-American sociology, because the latter is perceived by many as more practical and "closer to reality." Fourthly, Volker Meja, Dieter Misgeld, and Nico Stehr (1987, p. 4) consider a fundamentally critical, intellectual attitude to be characteristic of sociology in Germany. This attitude can be found among conservatives and left-wingers as well as in the field of philosophy of science, and it indicates a strong impact on the intellectual and medial public:

This attitude has remained unchanged from Max Weber to the conservatives Arnold Gehlen, Helmut Schelsky, and Friedrich Tenbruck, from the politically engaged liberal Ralf Dahrendorf to the left-wing intellectuals of the Frankfurt School. It also characterizes the philosophers of social science associated with 'critical rationalism' (Hans Albert, Ernst Topitsch) who have translated 'critical rationalism' into a form of 'Ideologiekritik', for which there is no parallel among members of Karl Popper's followers in other countries. The widespread participation of sociologists in public debates and disputes, which continues to this very day, indicates not only a particular and widely shared self-conception of sociologists as sociologists but also a receptivity to and an audience for sociological ideas and sociologically informed opinion which is considerably broader than in many English-speaking countries. (Meja et al. 1987, pp. 4-5; English in original)

This view contradicts the frequent lament encountered today that sociology is no longer present in the mass media. And indeed, recent quantitative analyses (Korte 2019) show that these complaints are not justified and that sociology is very present in the media. Sociology is visible in the feuilleton of the newspapers, but on television the interpretations offered by economists prevail. Moreover, sociology continues to have little influence on policy making, where political science and economics are preferably consulted.

\footnotetext{
${ }^{22}$ I would like to thank Andrea Ploder for her remarks on the differences between Germany and the United States in the field of empirical social research.
} 
Fifthly, in German sociology "self-critical crisis debates" (Meja et al. 1987 , p. 3, English in original) and controversies (Kneer and Moebius 2010) repeatedly occurred, which led to veritable splits between the different ideological camps and-as I will explain-these controversies still persist today. Some controversies developed between theories, others between theory and empirical sociology, between methodological approaches, and others even called into question the raison d'être of sociology as a whole. Besides substantial disagreements-such as that concerning Werturteilsfreibeit (freedom from value judgments), the relationship between theory and practice, or the deconstruction of sex/ gender, which were primarily methodological or epistemological issuesin the end these debates were also always struggles over power and interests within the sociological field.

One example of a conflict that has recently troubled and churned up the sociological field in Germany is the conflict between the GSA and a group of sociologists who have formed an Akademie für Soziologie (Academy of Sociology, hereafter "Academy"). ${ }^{23}$ According to its own statements, the objective of this Academy is to promote empirical-analytical sociology and quantitative social research. The conflict is particularly exacerbated by the fact that the representatives of the Academy claim that only they would pursue "truly" scientific, rational, and evidence-based sociology. A veritable "craving for rationality" dominates the statements of the members of the Academy, similar to what Friedrich Tenbruck (1979, p. 106, fn. 30) had already identified in the sociological reception of positivism and analytical philosophy of science half a century earlier. The Academy openly advocates a claim to the sole and "true" representation of sociology, which is perhaps not surprising in the struggle for increasingly scarce resources. With this claim, the Academy attempts to determine the generally defining value of the sociological field, which, from their point of view, lies in empirical-analytical sociology. Basically, this is a new version of the old dispute between nomothetic and ideographic conceptions of

\footnotetext{
${ }^{23}$ For further information on the Academy see their website https://akademie-soziologie. de/akademie/. On the conflict, see the websites http://blog.soziologie.de/2017/11/wasfuer-eine-wissenschaft-soll-die-soziologie-sein/ and http://blog.soziologie.de/2017/11/ mit-einem-auge-ist-man-halb-blind-von-einheit-und-uneinigkeit-der-soziologie/ and https://wiso.uni-koeln.de/de/forschung/forschung-im-fokus/soziologischeraschermittwoch/ (all accessed November 20, 2019), Hirschauer (2021), and the articles by Hartmut Esser, Stefan Hirschauer, and Jörg Strübing in Zeitschrift für Theoretische Soziologie Vol. 7 (1) and 7 (2)/2018 and Vol. 1/2019.
} 
science, but intellectually it falls far behind corresponding discussions by Max Weber (whom the Academy readily refers to, though for strategic reasons), who did not exclusively advocated either one or the other conception of science.

In addition, however, the founding of the Academy and its separation from the large remainder of sociologists organized in the GSA was also influenced by current power relations in the entire academic field and the reputational gains possible there. The members of the Academy, with their quantitative and analytical orientation, with their "mathematization" of sociology, are closer to the dominant positions in the general academic field, the disciplines of the natural sciences and mathematized economics, and can therefore hope for greater overall reputational gains. Perhaps they also hope for a similar effect that mathematization had for economics: As David M. Kreps (*1950) showed, mathematization led to an inner coherence of economics, not only by excluding other paradigms, such as historical or institutional analysis, but also by establishing a kind of "monolingualism" that was spread by the formulaic language and that connected otherwise heterogeneous parts with each other (Kreps 1997, p. 62).

Already in the 1970s, René König cautioned that his students—similar to Goethe's The Sorcerer's Apprentice - considered the techniques of empirical methods and their refinement to be increasingly more important than the problems of the social world they wanted to investigate with them. Often, modeling and mathematization - as is the case with economics-does not promote a sense of the problems of society, but rather a sense of the problems in applying the techniques of modeling. The real problems are being sidelined in favor of the problems of modeling (Barber 1997, p. 96). ${ }^{24}$ David M. Kreps (1997) has given a formidable description

${ }^{24}$ William Barber (1925-2016) cites the essay by David Colander and Arjo Klamer, "The Making of an Economist," in Journal of Economic Perspectives I (2) (Fall 1987): 95-111, which was "sponsored by the American Economic Association, that reported results of surveys of graduate students at six of the nation's leading doctoral programs. One of its central findings was that 'graduates are well-trained in problem-solving, but it is technical problem-solving which has more to do with formal modeling techniques than with real world problems. To do the problems, little real world knowledge of institutions is needed, and in many cases such knowledge would actually be a hindrance since the simplifying assumptions would be harder to accept.' In addition, the survey data indicated that substantial majorities of the survey population perceived two skills as 'very important' to professional 
of this change in economics in the United States, which can now be increasingly observed among some sociologists in Germany as well, emphasizing both the loss of a sense of reality and the gain in power that mathematization brought with it: "The use of a powerful and somewhat obscure tool confers power on the user. As economists became convinced of the value of mathematical rigor, the reward system (based on peer review) reinforced this tendency" (Kreps 1997, p. 83, English in original).

The founding of the Academy of Sociology is also a reaction to the pluralization of sociological perspectives. The multiparadigmaticity that can be observed today is the result of both the complexity and the normatively infused, antagonistic constitution of the object "society"-a pluralization that once again makes sociology appear in crisis in the eyes of members of the Academy. This mood of crisis nourishes romantic and dogmatic hopes for unification, unified science, standardization, and a clearly defined identity of the discipline. The Academy's secession from the German Sociological Association is the expression of this longing for a "unified science." However, obviously not all researchers are allowed to participate in determining the path and direction of unifying, some are even denied the status of scientist. The members of the Academy reveal a belief in a homogeneous unified science, but this belief seems unrealistic and in reality also unsociological. After all, is it not the case that because of our object "society" (or the social), which is normatively permeated, there can only be pluralization in the sociological field, and no unity, because there are heterogeneous positions of interest that are reflected in the sociological field? We sociologists are ourselves part of society, not free-floating above it - we are embedded in society politically, economically, culturally, and familially. In accordance with the different spheres of value, relevances of meaning, and antagonistic spheres of interest of our object "society" and our constitutive and habitual integration in it, our respective sociological viewpoints cannot be homogeneous but can only remain diverse and divergent. The current debate would therefore benefit from more self-reflection. What is needed are more sociological analyses of the

success: 'being smart in the sense of being good at problem solving' and 'excellence in mathematics.' Some 68 percent of the respondents reported a belief that 'having a thorough knowledge of the economy' was 'unimportant'” (Barber 1997, p. 96, English in original). I became aware of the studies of Kreps and Barber by reading Lepenies (1997, pp. 74-92). 
opposing positions, like, for example, Schmitz et al. (2019) did it, that contextualize the different positions within the sociological field of power and that understand the emergence of these positions against the background of the history of the discipline. This is a sociological insight that can at least provide a sense of orientation. Thus, current developments prove once more that the historiography of the history of sociology has, in general, a self-reflexive, orienting, critical, and enlightening function for sociology, and this book should be understood in this sense.

Open Access This chapter is licensed under the terms of the Creative Commons Attribution 4.0 International License (http://creativecommons.org/licenses/ by $/ 4.0 /)$, which permits use, sharing, adaptation, distribution and reproduction in any medium or format, as long as you give appropriate credit to the original author(s) and the source, provide a link to the Creative Commons licence and indicate if changes were made.

The images or other third party material in this chapter are included in the chapter's Creative Commons licence, unless indicated otherwise in a credit line to the material. If material is not included in the chapter's Creative Commons licence and your intended use is not permitted by statutory regulation or exceeds the permitted use, you will need to obtain permission directly from the copyright holder.

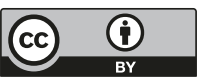

